\title{
Sustainable Weed Management for Conservation Agriculture: Options for Smallholder Farmers
}

\author{
Brian Sims ${ }^{1, *(1)}$, Sandra Corsi ${ }^{2}$, Gualbert Gbehounou ${ }^{2}$, Josef Kienzle ${ }^{2}$, Makiko Taguchi ${ }^{2}$ (D) \\ and Theodor Friedrich ${ }^{3}$ \\ 1 Engineering for Development, 3 Bourneside, Bedford MK41 7EG, UK \\ 2 Plant Production and Protection Division, FAO, Viale Delle Terme di Caracalla, 00153 Rome, Italy; \\ sandra.corsi@fao.org (S.C.); gualbert.gbehounou@fao.org (G.G.); josef.kienzle@fao.org (J.K.); \\ makiko.taguchi@fao.org (M.T.) \\ 3 FAO Representative in Bolivia, Calle 14, No 8008, Calacoto, La Paz, Bolivia; theodor.friedrich@fao.org \\ * Correspondence: sims.brian2@gmail.com; Tel.: +44-1234-271-699
}

Received: 25 May 2018; Accepted: 19 July 2018; Published: 1 August 2018

\begin{abstract}
Land degradation and soil fertility deterioration are two of the main causes of agricultural production stagnation and decline in many parts of the world. The model of crop production based on mechanical soil tillage and exposed soils is typically accompanied by negative effects on the natural resource base of the farming environment, which can be so serious that they jeopardize agricultural productive potential in the future. This form of agriculture is destructive to soil health and accelerates the loss of soil by increasing its mineralization and erosion rates. Conservation agriculture, a system avoiding or minimizing soil mechanical disturbance (no-tillage) combined with soil cover and crop diversification, is considered a sustainable agro-ecological approach to resource-conserving agricultural production. A major objective of tillage is supposed to be weed control, and it does not require very specific knowledge because soil inversion controls (at least temporarily) most weeds mechanically (i.e., by way of burying them). However, repeated ploughing only changes the weed population, but does not control weeds in the long term. The same applies to the mechanical uprooting of weeds. While in the short term some tillage operations can control weeds on farms, tillage systems can increase and propagate weeds off-farm. The absence of tillage, under conservation agriculture, requires other measures of weed control. One of the ways in which this is realized is through herbicide application. However, environmental concerns, herbicide resistance and access to appropriate agro-chemicals on the part of resource-poor farmers, highlight the need for alternative weed control strategies that are effective and accessible for smallholders adopting conservation agriculture. Farmers in semi-arid regions contend with the additional challenge of low biomass production and, often, competition with livestock enterprises, which limit the potential weed-suppressing benefits of mulch and living cover crops. This paper reviews the applicability and efficacy of various mechanical, biological and integrated weed management strategies for the effective and sustainable management of weeds in smallholder conservation agriculture systems, including the role of appropriate equipment and prerequisites for smallholders within a sustainable intensification scenario.
\end{abstract}

Keywords: smallholder farming; conservation agriculture; sustainable and ecological weed management; preventive; cultural and direct control methods of weed management

\section{Introduction}

Over the coming years, agriculture, particularly smallholder agriculture in developing countries, will face a convergence of pressures, including a growing population, increased migration, scarcity of 
labor, reduced land productivity, climate volatility and food insecurity. The sustainability of food and agricultural systems depends on not depleting natural resources; soils, especially, have been degraded by intensive crop production which has also jeopardized future food production in these areas. Much needs to be done to prevent further losses and to enhance the status of natural resources.

Food insecurity and poverty are significant development challenges and have fueled migration from rural to urban centers; while this has been occurring for centuries, it is now an accelerating phenomenon [1]. Moreover, arduous farm work and environmental degradation of the land is driving more youth to the towns seeking better opportunities, but often facing unemployment and further hardship-urbanization in low-income countries is often accompanied by high levels of poverty, unemployment and food insecurity.

The direct impact that urban migration brings to rural areas is the loss of workforce for agricultural tasks, which immediately affects productivity. Smallholder agriculture has certain labor peaks, among these is timely weeding, an important determinant of whether yields will be maintained or decreased. Mechanical weeding by human labor power (hoeing, scraping, rogueing, uprooting) is a laborious undertaking. Furthermore, the timeliness of the operation is a critically important factor, often requiring farm families to work long hours. This can limit the availability of farm labor for hand weeding, leading smallholders to limit their areas under production, governed by the affordability and availability of labor at peak times. In turn, the pressure for the youth to engage in farming is high, despite the fact that the agricultural sector is unattractive for this demographic [2].

Due to the high dependence on hand labor for weeding (and, often, primary land preparation), it is clear why both land and labor productivity remain at a low level. Continuous hand hoeing for weeding and land preparation are among the main causes for losses of soil organic matter (SOM). Experience shows that constant ploughing and hoeing can lead to the loss of soil fertility, mainly due to the oxidation of SOM and the exposure of bare soils to sun, wind and rain that cause run-off and surface erosion of the fertile top soil. This eventually makes soils unusable for farming.

Therefore, the question for many farmers is: what are the sustainable alternatives for crop production intensification? Conservation agriculture (CA) is a response to sustainable land management, environmental protection and climate change adaptation and mitigation. It promotes maintenance of a permanent soil cover, minimum soildisturbance, and diversification of plant species. It enhances biodiversity and natural biological processes above and below the ground surface, which contribute to increased water and nutrient use efficiency and to improved and sustained crop production. However, weed management may be critical for successful implementation of CA.

Fortunately, there are options that can reduce weed pressure and incorporate the idea that weed management, rather than total weed elimination, is the goal, and allow some weeds to play various roles in the agroecosystem. Of course, weeds need to be suppressed, especially at critical stages in the main crop cycle, but, instead of mechanical hoeing, the use of crop residues or mulch can help in this process. The use of selected leguminous crops for intercropping can also help suppress weeds. By overcoming a severe bottleneck in smallholder agriculture-hand weeding—with better agronomic and technology options, it may be possible to renew the attractiveness of the agricultural sector to rural youth.

This paper reviews the applicability and efficacy of various mechanical, biological and integrated weed management strategies for the effective and sustainable management of weeds in smallholder CA systems, including the role of appropriate equipment and prerequisites for smallholders within a sustainable intensification scenario.

\section{The Challenge of Weed Management in Conservation Agriculture}

Although CA is gaining recognition for its positive effect on soil conservation, it is still not widely known by many farmers around the world. For those who are familiar with the concept, a major challenge lies with weed management. Although, in the long run, some of the challenges reported in the literature for minimum or no-tillage systems, may not be valid for well managed CA crop 
production systems, they should be considered and anticipated, particularly for the first years, until the soil seed bank accumulated during tillage years has been substantially depleted.

In addressing weed control challenges, scientific studies have provided evidence that minimum and no-tillage induce shifts of weed population particularly towards perennial weeds, thus creating a long-lasting weed problem [3-17]. Moreover, annual weeds such as Kochia (Kochia scoparia (L.) Schrad.) and Russian thistle (Salsola iberica Sennen \& Pau) are controlled in tillage-based systems but often thrive in minimum and no-tillage systems [18]. In general, small-seeded weeds that require light to break dormancy will likely become the dominant weed species in minimum and no-tillage systems, including in the first years of adoption of CA. Thus, effective weed management is considered a critical issue and determines success in minimum and no-tillage based systems and CA [19-24].

Success with adoption of minimum and no-tillage, as reported in several publications, is attributed to the use of herbicides to control weeds, reduce inherent yield loss and cope with lack of labor in most countries [25-27]. Indeed in many cases, in minimum and no-tillage, herbicides are considered as an alternative to the primary tillage, done in tillage-based systems, for pre-planting weed control [28-36]. Several authors indicate that herbicides have reduced reliance on traditional tillage methods to control weeds and have led to the adoption of minimum and no-tillage practices [37]. Even when cover crops are grown for mulching and weed control, burn-down herbicides are often used to kill the vegetation before planting.

Herbicide-based no-till is problematic for several reasons. The herbicides commonly used for weed control, as a replacement for primary tillage, include 2, 4-D, dicamba, diflufenzopyr, fluometuron, glyphosate, glufosinate and paraquat. Alternatives are yet to be identified for some of the herbicides on this list that includes slightly (Class III) or moderately (Class II) hazardous herbicides that can be harmful to human health and the environment. Actually, the challenge of using herbicides for weed control in minimum and no-tillage and CA is further complicated by the fact that mechanical incorporation of herbicides into the soil is not possible with no-tillage or ridge-till systems, which limits herbicide options to only post-emergence.

As a consequence of the use of herbicides, resistance of several weed species in minimum and no-tillage systems has been reported, and cases of multiple-resistance of the same weed species to several herbicides have also been documented [38,39]. For example, cutleaf evening primrose (Oenothera laciniate Hill) has become resistant to glyphosate and paraquat $[33,40,41]$. Therefore, alternatives to herbicides should be promoted to support adoption of CA in a farming environment where resistance to herbicides has occurred.

Commercial release of glyphosate resistant crops has simplified weed control and in some regions the adoption of minimum and no-tillage, however, a negative aspect is that multiple applications of the herbicide are now typical, in the absence of other weed management strategies (including those before crop emergence and additional in-season treatments to control weeds that emerge after crop planting). Such a huge selection pressure induced by the use of a single herbicide has quickly led to the emergence of glyphosate-resistant weeds [42-47]. CA systems, with their emphasis on crop rotations and associations, will reduce weed pressure, however, there is a challenge for farmers who engage in $\mathrm{CA}$ in an environment where resistance to glyphosate has occurred, as this will reduce the applicability of the herbicide.

Clearly, unless weed management is sustainably addressed in CA, particularly in the first years, weed pressure, weed resistance and inherent crop yield losses may deter farmers from adopting conservation practices such as direct seeding. Instead, farmers will continue to rely on tillage which contributes to problems such as soil erosion, degradation of soil quality, high carbon footprint and yield reduction in the long run [48-52].

Soil erosion and soil degradation, inherent in tillage-based systems, increase environmental pollution from agricultural chemical inputs such as fertilizers and pesticides [53]. In fact, soil erosion and degradation jeopardize sustainability of crop production and ecosystem services as well as threaten global food security in the long run [54]. 
To avoid soil erosion and degradation and to improve soil health, CA appears to be an appropriate solution [55]. However, to support adoption of CA, weed management challenges should be anticipated and addressed with practical solutions, particularly for small-scale farmers, because they are vulnerable and may quickly get trapped in a vicious weed cycle that goes along with poverty and migration as depicted in Figure 1.

Vicious weed circle in most developing countries

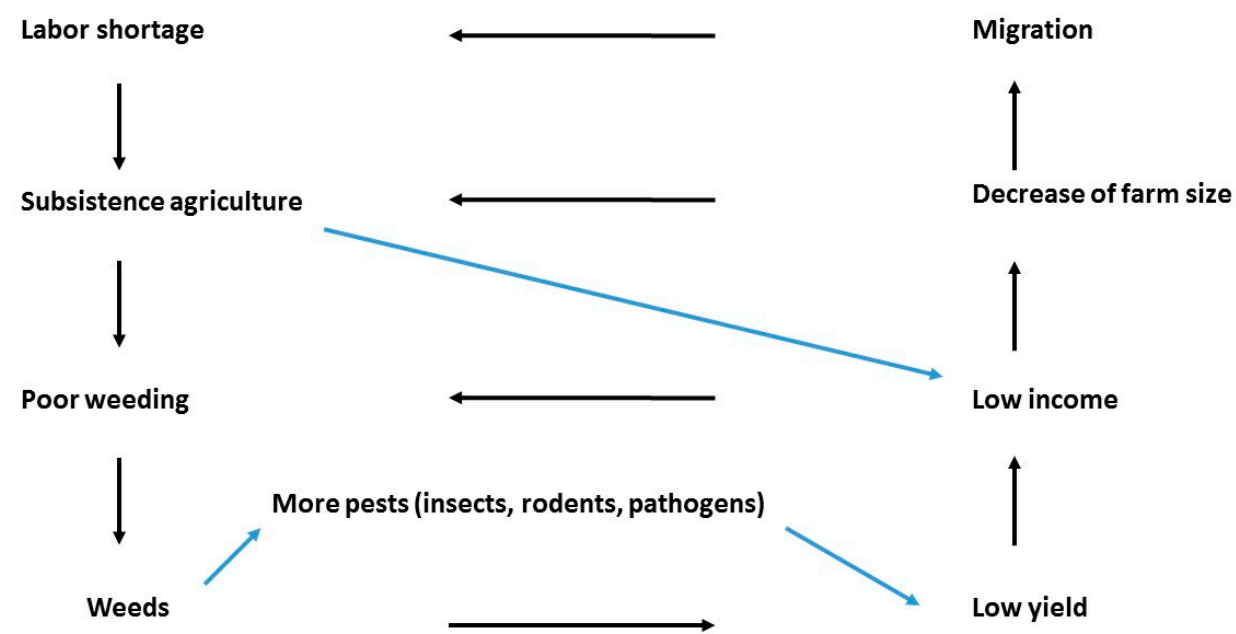

Figure 1. The vicious weed cycle that can affect smallholder farmers' crop yields in developing countries. (Adapted from [56]).

The vicious weed cycle is real in most developing countries, particularly for smallholders, because when a weed population evolves in a field it is relatively constant from year to year, whereas insect and disease outbreaks can be sporadic. Moreover, weeds compete with crops for the same resources: water; nutrients; light and carbon dioxide [57]. Furthermore, weeds are alternate hosts and harbor crop pests and pathogens. In addition, some weeds lack autotrophy and fully develop only by parasitizing crops or wild hosts. This is the case with several species of Striga, Orobanche, Cuscuta, Cassytha, etc. [58]. As a result of the interference of speargrass (Imperata cylindrica (L.) P.Beauv.) yield loss can be as high as $80 \%$ in cassava (Manihot esculenta Crantz) and $50 \%$ in maize (Zea mays L.) $[59,60]$. Heavy infestations of parasitic weeds often inflict $60 \%$ to $90 \%$ yield loss [61]; in China, ten million tons of rice are lost annually due to weed interference [62]. Weedy rice (Oryza spp.), a close relative of cultivated rice (Oryza sativa L. or Oryza glaberrima Steud.), can cause up to $70 \%$ yield loss to cultivated rice $[63,64]$.

\section{Sustainable Weed Management Methods in Conservation Agriculture}

\subsection{Preventive Weed Management}

Preventive weed management focuses on impeding the introduction of new or additional weed populations and reducing the overall emergence and propagation of weeds in the field [65].

For preventive weed management understanding what type of weeds are prevalent in the field and why, is important. Important information includes mode of reproduction, locations of greatest weed densities, and weed population seasonal dynamics. The farm weed flora are largely influenced by climate and the agroecological status of the field. Thus, farmers need to be aware of the lifecycle of the weed species and have the knowledge on when to take the necessary action in order to prevent multiplication of the weed population [66]. The following are examples of actions that can be taken to prevent weed pressure building. 


\subsubsection{Quality Planting Material and Clean Equipment}

To ensure that weed propagules are not introduced to the field from the external environment, use of good quality crop seeds, clean machinery or tools, uncontaminated sources of irrigation and manure applied, are all important.

Quality planting material devoid of weed propagules is particularly important to avoid propagation of noxious weeds, specified by law as being undesirable, troublesome and difficult to control because of their aggressive biological characteristics and geographical coverage. A list of major noxious weeds in sub-Saharan Africa is provided in [67].

\subsubsection{Reduced Weed Seed Bank in Ecological Weed Management}

Reducing the weed seed bank is particularly important during the first 2-3 years after transition to CA, as the seed bank in the soil will likely be well filled initially. To deplete the weed seed bank, weed seed-set should be avoided by all means and needs to be addressed in a holistic way.

This section discusses the methods that can be used to reduce the weed seeds available in the soil to provide the next generation of weed plants that can potentially compete with the crop.

- Seed predation in ecological weed management

Surface accumulation of seeds under no-tillage should increase their susceptibility to predation by insects, rodents and birds [68]. This can be a useful avenue for ecological weed management [69]. Less disruptive (or zero) soil tillage coupled with greater plant populations and diversity have been found to favour weed seed predation, especially by arthropods. A positive example is the use of cover crops which have often been found to encourage weed seed predating insects [70].

- $\quad$ Beetle strips

One way of encouraging beetles and other seed predating arthropods into the cropping area is by means of establishing beetle banks at strategic points in the fields (Figure 2). Beetle banks can comprise natural vegetation, or, if weed seeds are likely to be a problem, can be sown with coarse and tussocky grass species (such as Dactylis and Phleum spp. in temperate regions [71]).

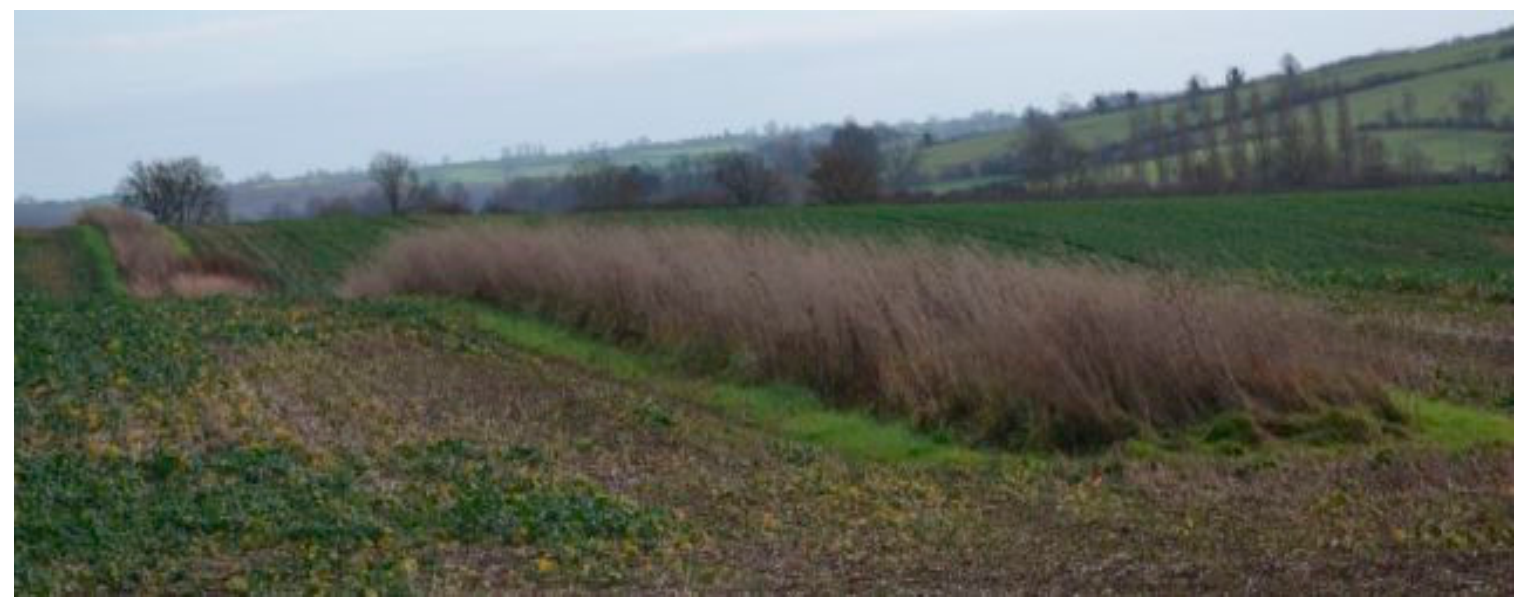

Figure 2. Beetle banks not only provide biological control of crop pests but can, when established on the contour, control surface runoff. (Photo: B Sims).

The banks not only provide a haven for seed predators, but also for predators of crop pests such as slugs and aphids. Rove and ground beetles (Staphylinidae and Carabidae respectively) are particularly useful in this respect in temperate climates. Banks can be augmented by leaving (or establishing) vegetation in the field margins and can be sown with nectar- and pollen-rich flora which will encourage 
pollinating insects-especially bees. Beetle banks established on the contour will also have an effect on reducing the length of run-off slopes and, as they slow any overland water flow, will encourage sedimentation of any soil particles [72]. Thus the banks are dual purpose, serving both as a refuge for useful predators and a brake on potential soil erosion.

\section{- $\quad$ Seed decay}

Weed seed decay is a means of reducing the weed seed bank and is, according to Bàrberi [70], still a poorly understood mechanism that includes, for example, the creation of soil conditions that encourage fungal infection of weed seeds. A method of controlling the notoriously noxious weed of cereal crops-blackgrass (Alopecurus myosuroides Huds.) —with no-tillage practices is a good example [68,73]. Up to $80 \%$ of blackgrass seeds perish each year in undisturbed (i.e., direct-drilled) soil and so only $20 \%$ of the previous year's seed bank will germinate. After ten years of no-tillage one farmer in Lincolnshire, UK, finds that occasional hand-rogueing is all that is required.

- Increased germination

Weed seeds can be encouraged to germinate and then be eliminated by mechanical or chemical control methods [15]. Generally, this technique will be marginal to CA systems if it involves excessive mechanical manipulation of the soil surface to encourage weed seed germination in a favorable 'seed-bed'. In smallholder situations, with limited land area and little mechanization, light surface scraping of the soil with the hand-hoe can be enough to initiate a phytochrome-mediated germination process in certain weed seeds [74]. Emerged seedlings can then be eliminated during a subsequent surface scraping operation [53] and this light operation can be considered compatible with CA. Phytochrome-mediated weed seed germination is also reduced with direct planters designed to cover the minimally disturbed seeding slot with soil and mulch to create 'invisible' no-tillage seeding and so reduce weed germination and emergence [75].

Encouraging weed germination by soil cultivation is not, as we have seen, compatible with true CA systems where the soil remains undisturbed and is covered by organic residues [76]. Weed seeds incorporated in the soil profile can remain dormant resulting in lower weed densities under a no-tillage regime. With weed seeds becoming more concentrated in the upper soil profile under CA [73], it can become possible to eliminate the first flush of germination before establishing the crop-in effect a type of stale seed-bed taking advantage of suicidal weed seed germination which is subsequently controlled with herbicides.

\section{- Solarization}

The elimination of weed seeds by thermal treatments, such as solarization, has limited potential in CA systems. It can only be considered as potentially applicable in situations of low biomass production which limit soil surface mulch cover with its weed-suppressing attributes. Solarization is achieved by placing plastic sheeting over the soil surface [53] which increases the soil surface temperature to a level sufficient to kill weed seeds. The problem is that high temperatures can also be lethal to bacteria and fungi [53] and so this method of weed seed elimination is not entirely compatible with CA and should only be used for particularly problematic weeds, such as noxious weeds that farmers have the obligation by law to eliminate from their fields. Yellow nutsedge (Cyperus esculentus L.) can be controlled by using clear plastic sheet cover for 90 days during a summer fallow [53]; but, of course no crop could be grown during this time. The practice is also of little use against weed seeds that have been deeply buried by soil inversion tillage.

\subsubsection{Prevention of Weed Seed Production and Shedding in Ecological Weed Management}

Rather than killing emerged weeds, perhaps a better strategy would be to prevent additional weed seeds from being shed and then stored in the soil seed bank. The following are some possibilities to help achieve this goal: 


\section{- Harvest weed seed control}

Smallholders will often have access to combines for cereal crop harvesting via mechanization service providers offering a custom hire service to multiple clients. Consequently, methods to harvest weed seeds at crop combining time are both very effective at reducing the soil weed seed bank and relevant to smallholder CA systems. Harvest weed seed control practices include chaff carts, narrow-windrow burning, weed seed milling and bale-direct systems [77].

Chaff carts are attached to the rear of the combine harvester to collect chaff and weed seeds and transfer them to a wheeled bulk collection bin-the chaff cart-for removal from the field for safe disposal (usually by burning).

In narrow-windrow burning the combine incorporates a chute at the rear to direct chaff and weed seeds into a narrow row-this could be along the combine wheel track and so is especially useful in controlled traffic systems. These narrow rows are subsequently burned (the concentrated chaff reaches very high temperatures which are lethal to weed seeds). Note that the entire field is not burned and the dispersed crop residue (straw and stover) is left as a surface mulch. However, there is some loss of nutrients to the system when the chaff and weed seed mixture is destroyed.

Weed seed milling (for example with the Harrington Seed Destructor [78]). Superficially similar to the chaff cart, the weed seed mill is trailed behind the combine. The chaff/weed seed mixture is collected by a hydraulically driven cross auger and fan and then forced through a cage mill with rotating blades that pulverize the seed and force out the flour through the cage. The crushed mixture, with all its nutrients, can then be returned to the field [79]. Multi-stage hammer mills can also be employed.

Finally, the bale-direct system comprises a trailed baler which captures the chaff/weed seed mixture and bales it for removal from the field.

- Weed header

It is important to prevent weeds that do become established in a crop from producing and shedding seeds. To remove weed flowers growing above crop height a weed header can be used to decapitate them [80]. The power-take-off-driven machine has a series (14 on the $10 \mathrm{~m}$ version) of 4-blade horizontal rotors beneath the canopy (Figure 3). The machine must be used before the weed seeds fully mature and this usually means within a few days of the seed head appearing above the crop. It can be a highly effective tool in organic farming and has also been found to give good control of the previously mentioned notorious blackgrass in temperate climate agriculture [81].

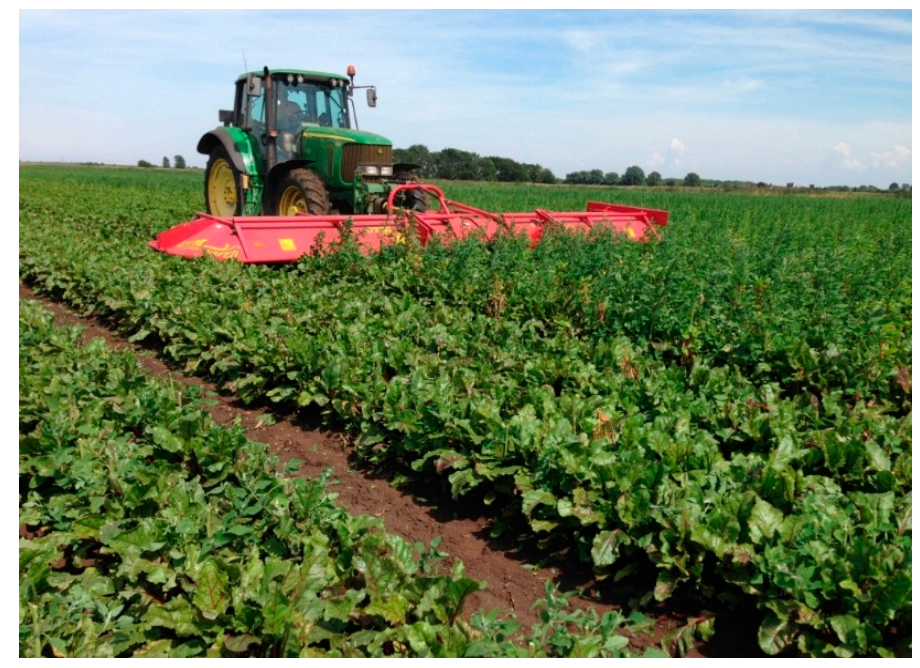

Figure 3. A weed header (Weed Surfer) in action topping weed seed heads protruding above an organic beetroot (Beta vulgaris L.) crop (Photo: S Briggs). 


\subsection{Cultural Weed Management}

\subsubsection{Reduction in Seedling Emergence}

- Identification of farm weed flora and most suitable initial crop

As described briefly in preventive weed management, the first step of effective weed management is to understand the farm weed flora. Weed proliferation depends on a variety of factors, such as soil cover and soil moisture. Depending on what type of weeds are present in the field, and what crop is intended to be grown, the farmer should understand (or be advised on) the economic threshold of weeding the existing weed population. Weed populations tend to thrive in similar conditions to those of the intended crop, so continuous production of the same or similar crops on the same land can enhance the proliferation of a certain weed species. When converting to conservation agricultural practices from conventional practice there may be an initial stronger weed establishment, and it is advisable to select more competitive types of crops. In general cereal crops are considered more competitive than leguminous crops [82]. However, on farms where a parasitic weed such as Striga (Striga hermonthica (Delile) Benth.) on cereal crops is of a major concern, preference should be given to leguminous trap crops that induce suicidal germination. Suicidal germination induced by a leguminous trap crop will deplete the Striga seed bank and also improve soil fertility through biological nitrogen fixation.

\section{- $\quad$ Critical period of weeding}

Crops are able to resist some weed pressure, and it is critical to understand what level at what growing period weed pressure/density can be tolerated and does not reach the economic threshold. Perhaps this is the most difficult decision farmers need to make, as the weed-crop dynamic is affected by multiple factors. From this perspective it is important that the yield reducing potential of the weed species is known to the farmer or the extension agent advising the farmer on weed management.

- Crop rotation and trap crops

A good crop rotation is a key element of a forward-looking management plan to reduce weed pressure and hence time and cost of weed management over time, and any effort to promote CA should emphasize the importance of an intensive (in space) and diversified (in time) crop rotation in support of no-till. There are different reasons for this and different rules to sequence the crops in rotation.

The priority in CA is to avoid leaving the soil bare. Crop, and especially cover crop, rotations can also include species that provide a quick and dense ground cover to outgrow the weeds, or species that can produce large quantities of slow decomposing biomass that can then be followed by a main crop. If the growing season is too short and sufficient water is available, the second crop can be relayed into the main one, or a cover crop can be grown for mulch production purposes. In this case the cover crop does not necessarily need to complete its growing cycle and produce seed. Other rules for a good crop rotation are that low residue crops should not follow other low residue crops; and that weed suppressing crops should precede slow-growing crops because these are more susceptible to weed competition.

As mentioned earlier, continuous production of a crop in a given field can promote proliferation of certain weed populations, blackgrass in cereal crops is a prime example. To cut this cycle, crop rotation is an effective cultural management technique. Introducing different types of crops into the system can help disrupt the spatial competition between crops and weeds both above-and under-ground. Crop rotation of annual and biennial or perennial crops can be effective, as well as graminaceous and leguminous crop rotations. They should maintain a positive nitrogen balance and ensure a balance of cash crops and functional crops.

Incorporation of crops with allelopathic characteristics to inhibit weed growth could also be considered; historically, crops such as buckwheat (Fagopyrum esculentum Moench), black mustard 
(Brassica nigra L.), sunflower (Helianthus spp.), black walnut (Juglans nigra L.) and cereal crops such as sorghum (Sorghum bicolor (L.) Moench), wheat (Triticum spp.), barley (Hordeum vulgare L.), oats (Avena sativa L.) and rye (Secale cereal L.) have been widely reported to suppress annual weed species [83]. They are crops producing allelo-chemicals that can inhibit the growth of another plant. The biochemical compounds produced by allelopathic plants are not known to be harmful to humans; they are usually volatile and broken down in a short amount of time [83]. Allelopathic cultivars can also be considered for incorporation into the crop rotation.

With regard to trap crops, recommended to deplete the seed bank of parasitic weeds, examples include varieties of cowpea (Vigna unguiculate (L.) Walp.), soybean (Glycine max (L.) Merr.) and peanut (Arachis hypogaea L.) that induce suicidal germination of the seeds of Striga [84]. They stimulate Striga seeds to germinate while they are false hosts that cannot be parasitized. Thus, germinated seeds die off and the Striga seed bank is substantially depleted.

- Photo-control

Photo-control of weeds is done, in CA, through night time direct planting, to reduce the germination of weed seeds that are light sensitive [85]. While the effectiveness of this method is widely debated, it is seen as a potential component of an integrated weed management regime. Depending on what weed flora are present, it can be determined whether this method would be an effective one or not. Seed germination tests with and without light can be performed to assess the presence of light sensitive species.

\section{- $\quad$ Mulching}

Mulching provides soil cover when the crop is not present or during the planting season. The main function of the mulch is to prevent/reduce light from reaching the soil surface to inhibit weed germination. Under CA, use of organic mulch (live/green mulch or crop/plant residue) is desired, although there are non-living mulch materials such as plastic widely used in different cropping systems. In order to function effectively, mulch requires to be thick enough to cover the soil surface sufficiently.

When using crop residues, it is important to ensure that the residue is evenly distributed on the soil surface to complete the cover. Distribution of residue can be done mechanically during harvest, or manually. However, this could be a labor intensive activity depending on the type of residue and biomass used for mulching. Farmers must assess biomass and labor availability vis a vis weed pressure. In semi-arid regions and in smallholder farms, crop residue may not be readily available, or compete with use for animal feed.

Other benefits of using (organic) mulch include conservation of soil and its moisture, regulation of soil temperature, and reduction of pests and diseases. However, when excess moisture is on the ground, fungal disease can increase and pests such as slugs and rodents may become an intermittent problem $[6,7]$.

\subsubsection{Improved Crop Competitiveness}

- Timeliness of seeding operations

Timely seeding of crops is essential in dry climates to ensure the efficient use of soil moisture and of the growing season. Depending on the type of weeds present, seeding timing can be adjusted to improve the crop competitiveness. Here again, a good understanding of weed type and its life cycle is important, as they also have a specific germination condition and timing [86].

- Seed rate and sowing pattern

Adjusting the crop density can also contribute to reducing weed population and increase crop competitiveness. This is due to the crop increasing its leaf area index and suppressing the weed germination or growth. 
- Transplanting

Transplanting can help give crops an advantage of early growth to increase its competitiveness. Rice transplanting in a flooded field is a typical example of this practice, but other grain crops such as sorghum and millet (several species of Poaceae) may also be transplanted. Transplanting of sorghum or millet, drastically reduces Striga parasitism and improves yield on infested farms. This is a common practice in sub-Saharan Africa [61].

\section{- Fertilization}

Weed species and crop species compete for light, water and nutrients. Targeted fertilization can give an advantage to the intended crop. In the specific case of the root parasitic weed Striga, targeted application of nitrogen and phosphorus fertilizers may substantially reduce infestation on cereal crops.

- The role of irrigation

Similar to fertilization, targeted irrigation such as drip irrigation can provide an advantage to the main crop. At the other end of the spectrum, flooding is also used as a way to reduce weed germination and growth; however, if the flooding is maintained for a longer period it affects the aerobic soil life which is again detrimental in CA systems.

- Competitive genotypes

Within a species, faster growing varieties may have an advantage over slow maturing varieties. Genotypes that have dwarf characteristics, or broader leaf area index may also have an advantage. When choosing the variety to plant, these criteria can be taken into consideration depending on the weed types present in the field. Crop cultivars with allelopathic characteristics could be considered also; however, the use of allelopathy is not widely known and further research is required to assess this characteristic in many plant species.

- Multi-cropping systems

To some extent this section overlaps with the previous section on crop rotation; our intention is to reinforce the message that increased biodiversity in cropping systems is generally beneficial in ecological weed management. Multi-cropping systems include intercrops, living mulches or cover crops, relay cropping and agroforestry. The wider the crop rotation, the more efficient the weed control [87]. The inclusion of species that provide a rapid and dense ground cover smothers weeds. In particular, embracing enough grasses produces a large quantity of slow decomposing residues. Examples of high biomass production mulch crops include: cereal rye, sorghum, radishes (Raphanus spp.), and legumes such as hairy vetch (Vicia villosa Roth).

During pre-emergence and growth of the main crop, cover crops can be used to suppress weed germination either physically or allelopathically. To shade out weeds, the crop rotation should produce adequate biomass by crop successions and/or outcompete weeds by fast growth and dense canopy cover. Dense seeding provides a better ground cover and shades out, and thus suppresses, weeds. Although a narrow spacing between main crop rows might hinder establishment of a relayed cover crop, it reduces weeds.

- Push-pull

The push-pull system developed for African cereal systems [70] (p. 24) is useful both for its control of maize stem-borer (Busseola fusca Lepidoptera: Noctuidae) and the parasitic witch weed (Striga). The way the system works is as follows [88]: maize is intercropped with silver-leaf desmodium (Desmodium uncinatum (Jacq.) DC.) and the fodder crop Napier grass (Pennisetum purpureum Schumach. 
1827) is planted around the field border. Desmodium produces volatile chemicals which repel the stem-borer adult moths by giving a signal that the area is already infested. The moths are 'pushed' to the Napier grass where the larvae do not thrive. Furthermore, desmodium behaves as a 'false host' for witch weed stimulating its germination without being parasitized. In this way a desmodium cover crop can, through suicidal germination, practically eliminate Striga in a couple of seasons.

\subsection{Direct Weed Management}

Once weeds are established in a crop, then they must be dealt with by direct weed control which can include chemical, mechanical and biological methods.

\subsubsection{Mechanical Methods in Ecological Weed Management}

Ploughs and other soil-engaging implements have been (and are being) used in non-CA systems principally to control weeds without the need for very specific knowledge because soil inversion controls most weeds mechanically (i.e., by way of burying them or cutting below the soil surface). This type of management is not an option for CA where soil disturbance must be kept to an absolute minimum.

Avoiding ploughing requires other measures of weed control including the regular observation of the development of weed populations. When cover crops can be rolled and crimped at precisely the right growth stage to ensure their desiccation before main crop direct sowing, weed competition is minimal [89].

Weed management in the growing crop should be achieved in the multiple ways discussed in this paper-principally through competition, but also with inter-row knife rollers [90] and the judicious use of herbicides where necessary. The aim is to minimize the yield-depressing effects on crops from weed competition for light, nutrients and moisture—and not necessarily to completely eliminate all traces of weeds [90].

Manual control of residual weeds in CA main crops can be managed in smallholder CA systems through a combination of surface scraping with hand hoes [91], slashing with machetes and hand-pulling or rogueing. Tall weeds growing in the main crop can be effectively controlled and prevented from producing seeds by a weed header as discussed earlier.

In some cases it might be sufficient to decapitate the weeds when they are flowering, in others they might be suppressed by cutting or rolling until the crop is tall enough to suppress the weeds.

\subsubsection{Biological/Agronomic Methods in Ecological Weed Management}

There is scope for increasing the control of weeds in CA through biological means, in addition to the increased crop/weed competition already discussed.

One example is the use of ducks in the duck-rice system. The use of animals to graze weeds is conceptually similar to weed seed predation [69]. The use of ducks for this purpose in the rice crop is popular in East Asia, especially in organic farming systems. Also the use of mobile cages with chickens on fields after harvest is practised in East Asia and can reduce weed seed populations while contributing fertilization. Other examples include [70]: fungal and insect control of Amaranthus and Convolvulus spp. However, it seems that the use of fungal and insect control methods has, to date, made a limited contribution to ecological weed management and the subject requires further research effort to realize its probably great potential.

\subsubsection{Chemical Methods in Integrated Weed Management}

It is beyond the scope of this section to go into further detail about the range of herbicides available to control weeds. The focus is on the best management practices for chemical desiccation, sustainable mechanization and the application of equipment relevant to smallholder farming systems, although a final note on herbicide seed coating is included. 
With regard to the chemical desiccation of weeds, the recommendations are the same as for tillage-based systems, i.e.,

- Water must be clean and free of suspensions.

- It is always safer to use non-selective herbicides at the labelled rate. Lower rates than the recommended one may not completely eradicate the weed, increasing the chance that the weed will produce seed. Under these circumstances, weeds developing from such seeds are more likely to be resistant to the herbicide.

- Changing herbicides from year to year or using different herbicides within the season (pre- and post-emergence) can prevent the build-up of resistant weed species.

- Weeds should be sprayed during vigorous growth early in the morning after dew has dried or late in the evening.

- Sprayers should always be tested before use for: correct operating pressure, nozzle overlap, individual volume/time discharge (calibrated for application volume). Aerial application of herbicides must be avoided.

- In the case of a heavy green mass at desiccation, up to three weeks should be allowed between spraying and seeding to enable dissipation of allelopathic products from root decomposition.

- However, in comparison to tillage-based systems, one category of herbicides is excluded from use in CA. These are pre-seeding herbicides which need to be incorporated into the soil.

- Herbicide application equipment

Equipment for appropriate herbicide application on smallholder farms is described in [90]. Where cover crops are grown in CA systems, their management can have similar characteristics to weed control and can also be achieved with herbicides. The equipment required can be powered by human or animal muscles or engine power and the most commonly used are sprayers equipped with hydraulic nozzles.

The most frequently used machine in smallholder CA systems is the ubiquitous lever-operated knapsack sprayer. Despite the relative simplicity of its design, knapsack sprayer operators will usually benefit from training in operation, calibration and maintenance [92]. One popular adaptation of the knapsack sprayer is to mount it on a wheeled chassis with one of the wheels operating the sprayer pump through an eccentric (Figure 4). With this configuration the operator can walk well ahead of the spray nozzles while applying herbicide uniformly over a wider boom width (usually $2 \mathrm{~m}$ ).

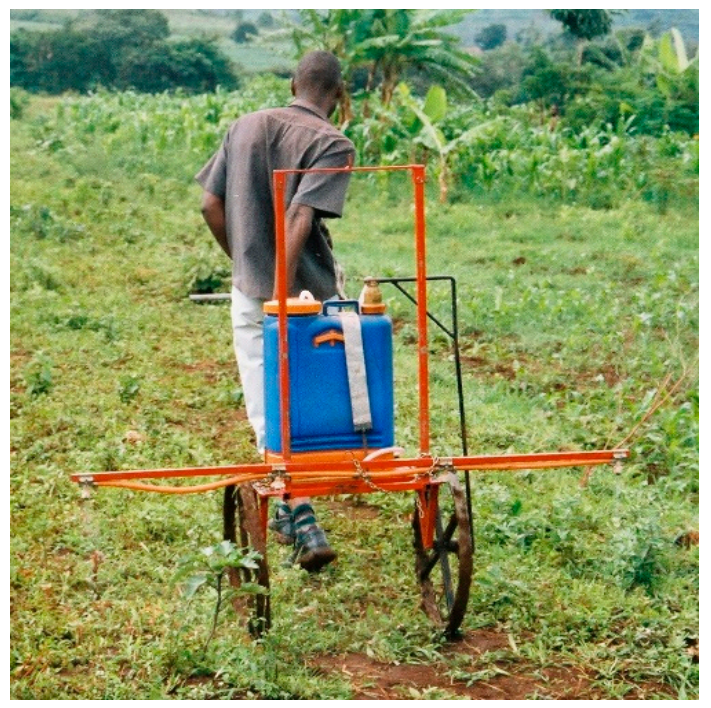

Figure 4. A knapsack sprayer fitted to a wheeled chassis. The four nozzles give a uniform $2 \mathrm{~m}$-wide spray swath well to the rear of the operator (Photo: B Sims). 
Knapsack sprayers are ideal for the spot treatment of individual plants or clumps of weeds, they can be adapted for controlled inter-crop weed management with the use of a spray shield or hood which prevents herbicide contamination of the main crop [93].

If draught animals or tractors (2- or 4-wheel) are available-either through individual ownership or via mechanization service providers-then conventional boom sprayers can be used with widths ranging up to $20 \mathrm{~m}$ or more (Figure 5). Other examples of herbicide application technologies for smallholders, not as popular as spray delivery via hydraulic nozzles, include simple weed wipers (such as the Zamwipe fabricated in Zambia) and controlled droplet application (CDA) sprayers. The Zamwipe [22] consists of a herbicide-moistened wick (usually glyphosate) which is manually brought into contact with the weeds. CDA sprayers use much lower volumes than hydraulic nozzles and produce droplets within a narrow size spectrum for increased efficacy and reduced drift. The droplets are produced by rapidly spinning plates or cones with toothed extremities.

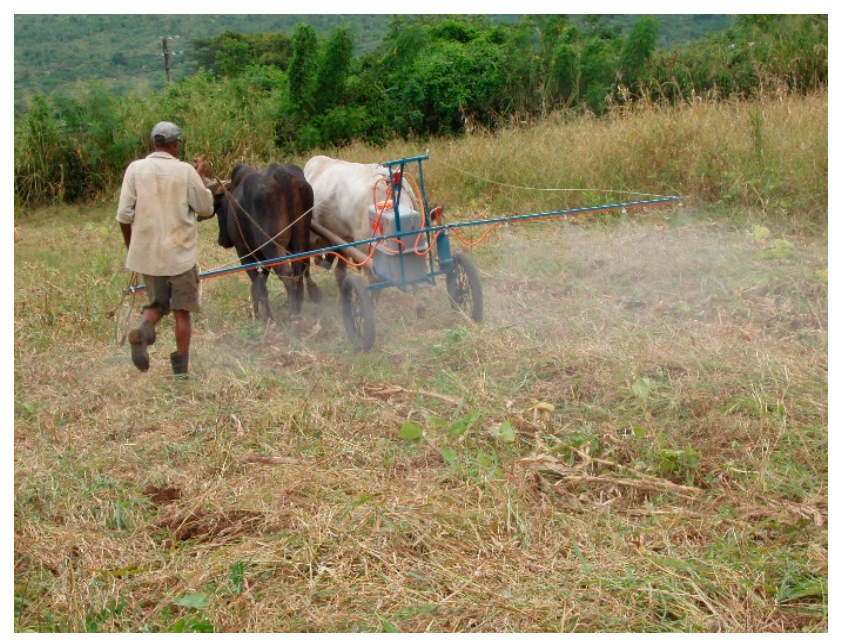

Figure 5. An animal-drawn sprayer for weed and cover crop management. The 80-L tank supplies a $5 \mathrm{~m}$ spray boom via a ground-wheel driven pump (Photo: B Sims).

\section{- Seed coating}

Worth mentioning under this section, in addition to the use of herbicide as described above, is herbicide seed coating to control Striga. The technology, designed as a component of integrated Striga control in maize, consists of a low-dose (30-45 $\left.\mathrm{g} \mathrm{ha}^{-1}\right)$ of imazapyr, a systemic acetolactate synthase-inhibiting herbicide, used for coating of imidazolinone-resistant (IR) maize seed. The technology, successfully tested in East Africa holds promise for reduction of Striga infestation and yield increase in areas where the parasitic weed inflicts high yield loss on maize [94].

\section{Conclusions}

Sustainable weed management, with its minimum use of herbicides, is an integrated approach to the challenge presented by the problem of weed interference and has a role to play in achieving sustainable crop production to feed the growing world population. Sustainable weed management comprises a suite of weed management options, including ecological weed management practices which preclude the use of herbicides. The underlying principle of sustainable weed management is to prevent the proliferation of weeds rather than to control them when they have appeared and started to cause damage. Also the aim is not always to eliminate weeds entirely, but to manage populations so that the impact on crop productivity is minimal. Critical to this process is the need for high levels of biodiversity manifested, for example, as crop rotations and associations with plenty of accommodation of natural weed and weed-seed predators. Cereal/legume combinations are important in this respect and agroforestry also has a key role to play in the future. 
There are many success stories of weed management through ecological means. The use of leguminous cover crops is a prime example, but so, too, is the concept of 'push-pull'. Using crops themselves to manage weeds whilst at the same time managing insect pests is a helpful and hopeful pointer to further successful developments. Soil tillage is generally not an option for sustainable weed management. Learning to use crops as functional agronomic inputs and as a (partial) replacement of chemical fertilizers and herbicides is knowledge intensive and implies a substantial change in the management of the farm and in the system of beliefs that is difficult to change for most farmers. This calls for the need for more and sustained capacity development efforts to promote acceptance/adoption of elements of innovation. The sustainable management of weeds is best achieved through the employment of 'many little hammers', rather than reliance on the sledge-hammer blow of herbicides.

For smallholders, especially in developing countries, it is important that extension services are available to better identify weed flora and to increase knowledge on the ways to tackle weed management in a more sustainable manner. Transition to a CA system from a conventional one may require strong incentive and support, as the first years may bring more challenges than benefits. Access to seeds for cover crops or alternative crops also may need to be facilitated. Policy makers and service providers may also want to consider an enabling environment for improved access to the various mechanical options available [92]. The enabling environment may include services such as credit for farmers, crop insurance, or input incentives that favor CA practices. While farmers remain focused on season by season production, adoption of CA would remain a challenge. A longer term perspective is necessary to understand the full benefits of CA.

What does the future hold as successful smallholders move into the exacting realms of the commercial sector? Looking well ahead, one possible scenario may involve new developments employing robots that can detect weeds using computer vision [95]. Commercial robotic machines, using RTK GPS (Real Time Kinematic Geographical Positioning System) will be coming available for spot weed control with herbicide [96], laser [97]; and non-soil inversion mechanical weed control systems for no-till crops may also become a possibility [98]. Being light and cheap, robotic weeding machines have the potential to practically eliminate damaging soil compaction caused by the passage of heavy spray rigs during the weed management operation (Figure 6). The use of small robot units operating in swarms and a cloud solution to plan, monitor and document all activities is underway in a collaborative project [99]. The current effort is concentrated on seeding but future use of big data sets will relate to soil compaction, plant diseases and weed management. Weed management options include mechanical cutting or spot application of herbicides in association with weed-mapping drones. As no blanket application is under consideration, this would be a useful step forward in reducing herbicide volumes in weed management [100].

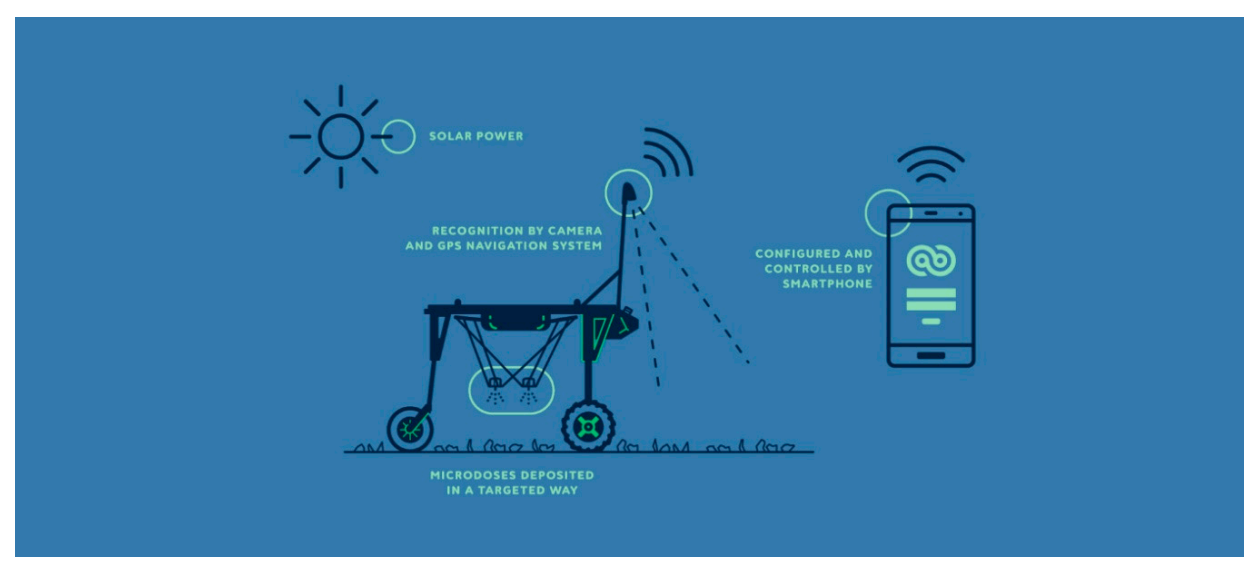

Figure 6. A commercially available autonomous robotic solar-powered weeder. Its light-weight (130 kg) minimizes soil compaction (ecoRobotix, Yverdon-les-Bains, Switzerland). 
This paper has attempted to list and evaluate options for ecological and integrated weed management in CA. In practice the choice of method (or methods) will reflect the locally available technical options and the economic environment of the smallholder sector, and so no inflexible solutions can be proposed. The aim has been to fill a gap in the available information on weed management in CA systems and the hope is that interest will be heightened and viable options be more tailored to local conditions in the future.

Author Contributions: All six co-authors contributed equally to all phases of the paper preparation process.

Funding: This research received no external funding.

Conflicts of Interest: The authors declare no conflict of interest.

\section{References}

1. Food and Agriculture Organization (FAO). The State of Food and Agriculture: Leveraging Food Systems for Inclusive Rural Transformation; Food and Agriculture Organization of the United Nations: Rome, Italy, 2017, ISBN 978-92-5-109873-8. Available online: http:/ / www.fao.org/3/a-I7658e.pdf (accessed on 25 May 2018).

2. African Union (AU). Malabo Declaration on Accelerated Agricultural Growth and Transformation for Shared Prosperity and Improved Livelihoods; African Union: Addis Ababa, Ethiopia, 2014; Available online: http:/ / www.resakss.org/sites/default/files/Malabo\%20Declaration\%20on\%20Agriculture_2014_ 11\%2026-.pdf (accessed on 24 May 2108).

3. Samson, N.; Légère, A.; Rioux, R. Chemical weed control options for zero-Tillage spring barley. Can. J. Plant Sci. 1996, 76, 383-386. [CrossRef]

4. Smith, E.G.; Peters, T.L.; Blackshaw, R.E.; Lindwall, C.W.; Larney, FJ. Economics of reduced tillage fallow-crop systems in the dark Brown soil zone of Alberta. Can. J. Soil Sci. 1996, 76, 411-416. [CrossRef]

5. Zanin, G.; Otto, S.; Riello, L.; Borin, M. Ecological interpretation of weed flora dynamics under different tillage systems. Agric. Ecosyst. Environ. 1997, 66, 177-188. [CrossRef]

6. Blackshaw, R.E.; Semach, G.; Li, X.; O'donovan, J.T.; Neil Harker, K. An integrated weed management approach to managing foxtail barley (Hordeum jubatum) in conservation tillage systems. Weed Technol. 1999, 13, 347-353. [CrossRef]

7. Streit, B.; Rieger, S.B.; Stamp, P.; Richner, W. The effect of tillage intensity and time of herbicide application on weed communities and populations in maize in Central Europe. Agric. Ecosyst. Environ. 2002, 92, 211-224. [CrossRef]

8. Carter, M.R.; Sanderson, J.B.; Ivany, J.A.; White, R.P. Influence of rotation and tillage on forage maize productivity, weed species, and soil quality of a fine sandy loam in the cool-humid climate of Atlantic Canada. Soil Tillage Res. 2002, 67, 85-98. [CrossRef]

9. Torresen, K.S.; Skuterud, R.; Tandsaether, H.J.; Hagemo, M.B. Long term experiments with reduced tillage in spring cereals. I. Effects on weed flora weed seedbank and grain yield. Crop Prot. 2003, 22, 185-200. [CrossRef]

10. Thomas, A.G.; Derksen, D.A.; Blackshaw, R.E.; Van Acker, R.C.; Légère, A.; Watson, P.R.; Turnbull, G.C. A multistudy approach to understanding 20 weed population shifts in medium to long-term tillage systems. Weed Sci. 2004, 52, 874-880. [CrossRef]

11. Conn, J.S. Weed seed bank affected by tillage intensity for barley in Alaska. Soil Tillage Res. 2006, 90, 156-161. [CrossRef]

12. Christoffoleti, P.J.; Pinto de Carvalho, S.J.; López-Ovejero, R.F.; Nicolai, M.; Hidalgo, E.; da Silva, J.E. Conservation of natural resources in Brazilian agriculture: Implications on weed biology and management. Crop Prot. 2007, 26, 383-389. [CrossRef]

13. Albrecht, H.; Sprenger, B. Long-term effects of reduced tillage on the populations of arable weeds. In Perspectives for Agroecosystem Management, 1st ed.; Schroder, P., Pfadenhauer, J., Munch, J.C., Eds.; Elsevier: New York, NY, USA, 2008; ISBN 9780444519054.

14. Norsworthy, J.K. Effect of tillage intensity and herbicide programs on changes in weed species density and composition in the south-eastern coastal plains of the Unites States. Crop Prot. 2008, 27, 151-160. [CrossRef]

15. Bajwa, A.A. Sustainable weed management in conservation agriculture. Crop Prot. 2014, 65, 105-113. [CrossRef] 
16. Ranaivoson, L.; Naudin, K.; Ripoche, A.; Affholder, F.; Rabeharisoa, L.; Corbeels, M. Agro-ecological functions of crop residues under conservation agriculture. A review. Agron. Sustain. Dev. 2016, 37, 1-17. [CrossRef]

17. Thierfelder, C.; Baudron, F.; Setimela, P.; Nyagumbo, I.; Mupangwa, W.; Mhlanga, B.; Lee, N.; Gérard, B. Complementary practices supporting conservation agriculture in southern Africa: A review. Agron. Sustain. Dev. 2018, 38. [CrossRef]

18. Vencill, W.K.; Banks, P.A. Effects of tillage systems and weed management on weed populations in grain sorghum (Sorghum bicolor). Weed Sci. 1994, 42, 541-547.

19. Bhagat, R.M.; Bhuiyan, S.I.; Moody, K. Water, tillage and weed interactions in lowland tropical rice: A review. Agric. Water Manag. 1996, 31, 165-184. [CrossRef]

20. Erenstein, O. Small holder conservation farming in the tropics and subtropics: A guide to the development and dissemination of mulching with crop residues and cover crops. Agric. Ecosyst. Environ. 2003, 100, 17-37. [CrossRef]

21. Mas, M.T.; Verdù, A.M.C. Tillage system effects on weed communities in a 4-year crop rotation under Mediterranean dry land conditions. Soil Tillage Res. 2003, 74, 15-24. [CrossRef]

22. International Institute of Rural Reconstruction (IIRR); African Conservation Tillage Network (ACT). Conservation Agriculture: A Manual for Farmers and Extension Workers in Africa; International Institute of Rural Reconstruction: Nairobi, Kenya; African Conservation Tillage Network: Harare, Zimbabwe, 2005, ISBN 9966-9705-9-2.

23. Samarajeewa, K.B.D.P.; Horiuchi, T.; Oba, S. Finger millet (Eleucine corocana L. Gaertn.) as a cover crop on weed control, growth and yield of soybean under different tillage systems. Soil Tillage Res. 2006, 90, 93-99. [CrossRef]

24. Giller, K.E.; Witter, E.; Corbeels, M.; Tittonell, P. Conservation agriculture and smallholder farming in Africa: The heretics' view. Field Crops Res. 2009, 114, 23-34. [CrossRef]

25. Phipps, R.H.; Park, J.R. Environmental benefits of genetically modified crops: Global and european perspectives on their ability to reduce pesticide use. J. Anim. Feed Sci. 2002, 2, 1-18. [CrossRef]

26. Fernandez-Cornejo, J.; McBride, W.D. Adoption of Bioengineered Crops; Economic Research Service, USDA: Washington, DC, USA, 2005.

27. Nakamoto, T.; Yamagishi, J.; Miura, F. Effect of reduced tillage on weeds and soil organisms in winter wheat and summer maize cropping on humid Andosols in Central Japan. Soil Tillage Res. 2006, 85, 94-106. [CrossRef]

28. Curran, W.S.; Lingenfelter, D.D. An Introduction to Weed Management for Conservation Tillage Systems. Conservation Tillage Series 1996, Number Two. Available online: https://extension.psu.edu/anintroduction-to-weed-management-for-conservation-tillage-systems (accessed on 23 July 2018).

29. Gaudard, L. Semis direct et "labour chimique"-L'expérience de la SODECOTON au Nord Cameroun; Coton et Développement: Paris, France, 1997; Volume 24, pp. 27-30.

30. Martin, J.; Gaudard, L. Paraquat, diuron and atrazine for the renewal of chemical weed control in Northern Cameroon. Agric. Dév. 1997, Special Issue, 29-41.

31. Locke, M.A.; Reddy, K.N.; Zablotowicz, R.M. Weed management in conservation crop production systems. Weed Biol. Manag. 2002, 2, 123-132. [CrossRef]

32. Diver, S. No-Till Vegetable Production: Non-Chemical Methods of Cover Crop Suppression and Weed Control by Appropriate Technology Transfer for Rural Areas-ATTRA Fayetteville, Arkansas. 2002. Available online: http:/ / attra.ncat.org/downloads/notill_veg.doc (accessed on 23 July 2018).

33. York, A.C.; Culpepper, A.S.; Stewart, A.M. Response of Strip-tilled cotton to preplant applications of Dicamba and 2, 4-D. J. Cotton Sci. 2004, 8, 213-222.

34. Tubbs, R.S.; Gallaher, R.N. Conservation Tillage and Herbicide Management for Two Peanut Cultivars. Agron. J. 2005, 97, 500-504. [CrossRef]

35. Blackshaw, R.E.; Molnar, L.J. Integration of Conservation Tillage and Herbicides for Sustainable Dry Bean Production. Weed Technol. 2008, 22, 168-176. [CrossRef]

36. Scopel, E.; Triomphe, B.; Affholder, F.; Da Silva, F.A.M.; Corbeels, M.; Xavier, J.H.V.; Lahmar, R.; Recous, S.; Bernoux, M.; Blanchart, E.; et al. Conservation agriculture cropping systems in temperate and tropical conditions, performances and impacts. A review. Agron. Sustain. Dev. 2013, 33, 113-130. [CrossRef] 
37. O'Connell, P.J.; Harms, C.T.; Allen, J.R.F. Metolachlor, S-metolachlor and their role within sustainable weed-management. Crop Prot. 1998, 17, 207-212. [CrossRef]

38. Puricelli, E.; Tuesca, D. Weed density and diversity under glyphosate resistant crop sequences. Crop Prot. 2005, 24, 533-542. [CrossRef]

39. Binimelis, R.; Pengue, W.; Monterroso, I. “Transgenic treadmill”: Responses to the emergence and spread of glyphosate-resistant Johnsongrass in Argentina. Geoforum 2009, 40, 623-633. [CrossRef]

40. Canon, S. Weeds Developing Resistance to Widely Used Herbicide. The Kansas City Star 2001. Available online: https:/ / www.iatp.org/news/weeds-developing-resistance-to-widely-used-herbicide-some-say (accessed on 23 July 2018).

41. Anderson, R.L. A multi-tactic approach to manage weed population dynamics in crop rotations. Agron. J. 2005, 97, 1579-1583. [CrossRef]

42. Ruiz, P.; Novillo, C.; Fernandez-Anero, J.; Campos, M. Soil arthropods in glyphosate tolerant and isogenic maize lines under different soil/management practices. In Conservation Agriculture, a Worldwide Challenge. First World Congress on Conservation Agriculture Madrid, Spain, 1-5 October 2001. Volume 1 Keynote Contributions; García-Torres, L., Benites, J., Martínez-Vilela, A., Eds.; XUL: Córdoba, Spain, 2001, ISBN 8493223719.

43. Everitt, J.D.; Keeling, W. Weed control and cotton (Gossypium hirsutum) response to preplant applications of Dicamba, 2, 4-D, and Diflufenzopyr plus Dicamba. Weed Technol. 2007, 21, 506-510. [CrossRef]

44. Johnson, W.G.; Davis, V.M.; Kruger, G.R.; Weller, S.C. Influence of glyphosate-resistant cropping systems on weed species shifts and glyphosate resistant weed populations. Eur. J. Agron. 2009, 31, 162-172. [CrossRef]

45. Soil Management and Conservation. Available online: https://www.ers.usda.gov/webdocs/publications / 41964/30293_soilmgmt.pdf?v=4114346 (accessed on 24 April 2018).

46. Fawcett, R.S. Overview of pest management for conservation tillage systems. In Effects of Conservation Tillage on Groundwater Quality: Nitrates and Pesticides; Logan, T.J., Lal, R., Dick, W.A., Eds.; CRC Press: Boca Raton, FL, USA, 1987; pp. 19-37.

47. Thomas, A.G.; Kelner, D.; Wise, R.F.; Frick, B.L. Comparing Zero and Conventional Tillage Crop Production Systems. In Manitoba Weed Survey (Publication 97-1); Manitoba Agriculture Soils and Crops Branch: Carman, MB, Cananda, 1997.

48. Day, J.C.; Hallahan, C.B.; Sandretto, C.L.; Lindamood, W.A. Pesticide use in U.S. corn production: Does conservation tillage make a difference? J. Soil Water Conserv. 1999, 54, 477-484.

49. Streit, B. Impacts of Tillage Systems, Crop Sequence, and Weed Control on the Development of Weed Populations and the Degradation of Herbicides. Ph.D. Thesis, Swiss Federal Institute of Technology, Zurich, Switzerland, 2001.

50. Shrestha, A.; Lanini, T.; Wright, S.; Vargas, R.; Mitchell, J. Conservation Tillage and Weed Management; Division of Agriculture and Natural Resources, University of California: Oakland, CA, USA, 2006.

51. Kok, H.; Papendick, R.I.; Saxton, G.E. Steep: Impact of long-term conservation farming research and education in Pacific Northwest wheat lands. J. Soil Water Conserv. 2009, 64, 253-264. [CrossRef]

52. Sattler, C.; Nagel, U.J. Factors affecting farmers' acceptance of conservation measures-A case study from north-eastern Germany. Land Use Policy 2010, 27, 70-77. [CrossRef]

53. Lee, N.; Thierfelder, C. Weed control under conservation agriculture in dryland farming systems of southern Africa. A review. Agron. Sustain. Dev. 2017, 37, 48. [CrossRef]

54. Montgomery, D.R. Dirt, the Erosion of Civilizations; University of California Press: Berkely, CA, USA; Los Angeles, CA, USA, 2007; 285p, ISBN 0520952111, 9780520952119.

55. Conservation Agriculture. Available online: www.fao.org/ag/ca (accessed on 2 May 2018).

56. Vissoh, P.V.; Gbehounou, G.; Ahanchede, A.; Kuyper, T.W. Weeds as agricultural constraint to farmers in Benin: Results of a diagnostic study. Neth. J. Agric. Sci. 2004, 52, 305-329. [CrossRef]

57. Parker, R. Water Conservation, Weed Control Go Hand in Hand. Drought Advisory EM4856. 2003. Available online: http:/ / cru.cahe.wsu.edu/CEPublications/em4856/em4856.pdf (accessed on 23 July 2018).

58. Parker, C.; Riches, C.R. Parasitic Weeds of the World: Biology and Control; CAB International: Wallington, UK, 1993; 332p, ISBN 0851988733.

59. Terry, P.J.; Adjers, G.; Akobundu, I.O.; Anoka, A.U.; Drilling, M.E.; Tjitrosemito, S.; Utomo, M. Herbicides and mechanical control of Imperata cylindrica as a first step in grassland rehabilitation. Agron. Syst. 1997, 36, 151-179. [CrossRef] 
60. Chikoye, D.; Manyong, V.M.; Carsky, R.J.; Ekeleme, F.; Gbehounou, G.; Ahanchede, A. Response of speargrass (Imperata cylindrica) to cover crops integrated with handweeding and chemical control in maize and cassava. Crop Prot. 2002, 21, 145-156. [CrossRef]

61. Gbèhounou, G.; Adango, E.; Hinvi, J.C.; Nonfon, R. Sowing date or transplanting as components for integrated Striga hermonthica control in grain cereal crops? Crop Prot. 2004, 23, 379-386. [CrossRef]

62. Zhang, Z.P. Weed Management in Rice in China. In Proceedings of the FAO Workshop on Echinochloa spp. Control, Beijing, China, 27 May 2001.

63. Labrada, R. The need for improved weed management in rice. In Proceedings of the 20th Session of the International Rice Commission, Bangkok, Thailand, 23-26 July 2002; Tran van, D., Duffy, R., Eds.; Plant Production and Protection, FAO: Rome, Italy, 2003; pp. 181-189.

64. Shivrain, V.K.; Burgos, N.R.; Sales, M.A.; Kuk, Y.I. Polymorphisms in the ALS gene of weedy rice (Oryza sativa L.) accessions with differential tolerance to imazethapyr. Crop Prot. 2010, 29, 336-341. [CrossRef]

65. Palou, A.; Ranzenberger, A.; Larios, C. Management of Herbicide-Resistant Weed Populations: 100 Questions on Resistance; Food and Agriculture Organization of the United Nations: Rome, Italy, 2008.

66. Cristoffoleti, P.; Carvalho, S.; Nicolai, M.; Doohan, D.; VanGessel, M. Prevention strategies in weed management. In Non-Chemical Weed Management: Principles, Concepts and Technology; Upadhyaya, M., Blackshaw, R., Eds.; CAB International: London, UK, 2007; pp. 1-16. ISBN 9781845932909.

67. Gbehounou, G. Guidance on Weed Issues and Assessment of Noxious Weeds in a Context of Harmonized Legislation for Production of Certified Seeds; Food and Agriculture Organization of the United Nations: Rome, Italy, 2013; ISBN 978-92-5-107996-6. Available online: http:/ / www.fao.org/3/a-i3493e.pdf (accessed on 24 May 2018).

68. Nichols, V.; Verhulst, N.; Cox, R.; Govaerts, B. Weed dynamics and conservation agriculture principles: A review. Field Crops Res. 2015, 183, 56-68. [CrossRef]

69. Gbehounou, G.; Bàrberi, P. Weed management. In Mainstreaming Ecosystem Services and Biodiversity into Agricultural Production and Management in East Africa: Technical Guidance Document; Food and Agriculture Organization of the United Nations: Rome, Italy; Secretariat of the Convention on Biological Diversity: Rome, Italy, 2016; pp. 29-45.

70. Bàrberi, P. Ecological Weed Management in Sub-Saharan Africa and the Pacific: A Review; Food and Agriculture Organization of the United Nations: Rome, Italy; Institute of Life Sciences, Scuola Superiore Sant'Anna: Pisa, Italy, 2016; 157p.

71. Sims, B. Conserving Biodiversity: The Allerton Project's Approach to Sustainable Food Production. 2016. Available online: https://drive.google.com/file/d/0BwyIPGne8KZ-aE96V2NQMFhiSUU/view (accessed on 12 April 2018).

72. Sims, B.; Walle, R.; Ellis-Jones, J. Hillside Systems. Guidelines for Research on Hillside Farms: Participatory Technology Development of Soil and Water Conservation Technologies; Silsoe Research Institute: Silsoe, UK, 1999; 52p, Available online: http:/ / www.engineering4development.co.uk/publications (accessed on 12 April 2018).

73. Sims, B.; Kassam, A. East Anglia branch visit to Tony Reynolds at Thurlby Grange farm: Farming in the Lincolnshire fens. Agric. Dev. 2015, 26, 51-52.

74. Mhlanga, B.; Cheesman, S.; Maasdorp, B.; Muoni, T.; Mabasa, S.; Mangosho, E.; Thierfelder, C. Weed community responses to rotations with cover crops in maize-based conservation agriculture systems of Zimbabwe. Crop Prot. 2015, 69, 1-8. [CrossRef]

75. Friedrich, T. Does farming require more herbicides? Outlooks Pest Manag. 2005, 24, 188-191. [CrossRef]

76. Matloob, A.; Khaliq, A.; Chauhan, B.S. Weeds of direct-seeded rice in Asia: Problems and opportunities. Adv. Agron. 2015, 130, 291-322.

77. Schwartz, L.M.; Norsworthy, J.K.; Barber, L.T.; Scott, R.C. Harvest Weed Seed Control—An Alternative Method for Measuring the Soil Seedbank. Division of Agriculture Research and Extension, University of Arkansas, USA, Agriculture and Natural Resources FSA 2180. Available online: https:/ / www.uaex.edu/ publications/pdf/FSA-2180.pdf (accessed on 24 April 2018).

78. Mowbray, E. Combine-Mounted Mill Crushes Weed Seeds on the Go. Farmers Wkly. 13 July 2017. Available online: http:/ / www.fwi.co.uk/machinery/combine-mounted-mill-crushes-weed-seeds-go.htm (accessed on 24 April 2018).

79. Harrington Seed Destructor. Available online: https://www.youtube.com/watch?v=EYvZJ_KjMKY (accessed on 24 April 2018). 
80. Cousins, D. CTM Harpley launches $10 \mathrm{~m}$ Weed Surfer. Farmers Wkly. 14 July 2010. Available online: http: //www.fwi.co.uk/machinery/ctm-harpley-launches-10m-weed-surfer.htm (accessed on 24 April 2018).

81. An Explanation of Why I See the Weed Surfer as a Useful Tool. Available online: https://www.youtube. com/watch?v=Z9hqsE3OZIg (accessed on 24 April 2018).

82. Blackshaw, R.; Anderson, R.; Lemerle, D. Cultural Weed Management. In Non-Chemical Weed Management: Principles, Concepts and Technology; Upadhyaya, M., Blackshaw, R., Eds.; CAB International: London, UK, 2007; pp. 35-48. ISBN 9781845932909.

83. Weston, L.; Inderjit. Allelopathy: A Potential Tool in the Development of Strategies for Biorational Weed Management. In Non-Chemical Weed Management: Principles, Concepts and Technology; Upadhyaya, M., Blackshaw, R., Eds.; CAB International: London, UK, 2007; pp. 65-76. ISBN 9781845932909.

84. Gbehounou, G. Striga control by restoring soil fertility. In Proceedings of the Abstracts of the III International Weed Science Congress, Foz do Iguassu, Brazil, 6-11 June 2000; Abstract Number 539. International Weed Science Society: Corvallis, OR, USA, 2000; pp. 260-261.

85. Juroszek, P.; Gerhards, R. Photocontrol of Weeds. J. Agron. Crop Sci. 2004, 190, 402-415. [CrossRef]

86. Hartzler, R.; Buhler, D. Ecological Management of Agricultural Weeds. In Ecologically Based Integrated Pest Management; Koul, O., Cuperus, G., Eds.; CAB International: London, UK, 2007; pp. 37-55, ISBN 9781845930646.

87. Corsi, S. Conservation Agriculture Training Guide for Extension Agents and Farmers in Eastern Europe and Central Asia; Food and Agriculture Organization of the United Nations: Rome, Italy, 2017; 158p, ISBN 978-92-5-409740-0.

88. Food and Agriculture Organization (FAO). Save and Grow in Practice: Maize, Rice, Wheat. A Guide to Sustainable Cereal Production; Food and Agriculture Organization of the United Nations: Rome, Italy, 2016; pp. 40-43.

89. Cover Crop Roller Crimping and Planting Video. Available online: https://www.youtube.com/watch?v= fW0ofAKESUg (accessed on 25 April 2018).

90. Sims, B.G.; Kienzle, J.; Mkomwa, S.; Friedrich, T.; Kassam, A.H. Mechanization of smallholder conservation agriculture in Africa; contributing resilience to precarious systems. In Conservation Agriculture for Africa. Building Resilient Farming Systems in a Changing Climate; Kassam, A.H., Mkomwa, S., Friedrich, T., Eds.; CABI: Wallingford, UK; Boston, MA, USA, 2017; Chapter 11; pp. 183-213. ISBN 9781780645681.

91. Mkomwa, S.; Lugandu, S.; Kuria, P.; Mutai, W. Empowering smallholder farmers with profitable and sustainable farming using conservation agriculture: The case of East Africa. In Conservation Agriculture for Africa. Building Resilient Farming Systems in a Changing Climate; Kassam, A.H., Mkomwa, S., Friedrich, T., Eds.; CABI: Wallingford, UK; Boston, MA, USA, 2017; Chapter 4; p. 58. ISBN 9781780645681.

92. Sims, B.G.; Kahan, D.; Mpagalile, J.; Hilmi, M.; Santos-Valle, S. Hire Services as a Business Enterprise. A Training Manual for Small-Scale Mechanization Service Providers; Food and Agriculture Organization of the United Nations: Rome, Italy; International Maize and Wheat Improvement Centre (CIMMYT): El Batán, Mexico, 2018; p. 125.

93. Association of Applied Biologists (AAB). International advances in pesticide application. Asp. Appl. Biol. 2006, 84, 524.

94. Kanampiu, F.; Diallo, A.; Karaya, H. Herbicide-coating technology: A unique approach to Striga control in maize. In Proceedings of the African Crop Science Conference, Volume 8, El-Minia, Egypt, 27-31 October 2007; African Crop Science Society: Brighton, UK, 2007; pp. 1095-1098.

95. Tillet, N.D.; Hague, T.; Grundy, A.C.; Dedousis, A.P. Mechanical within-row weed control for transplanted crops using computer vision. Biosyst. Eng. 2008, 99, 171-178. [CrossRef]

96. Medici Scolero, C. This Weed-Killing AI Robot Can Tell Crops Apart. 2018. Available online: https: / / www.cnbc.com/2018/06/04/weed-killing-ai-robot.html (accessed on 11 July 2018).

97. Realag Machinery Insider. This Robot Kills Weeds with Lasers. 2017. Available online: https://www. realagriculture.com/2017/11/this-robot-kills-weeds-with-lasers / (accessed on 11 July 2018).

98. Peruzzi, A.; Martelloni, L.; Frasconi, M.; Fontanelli, M.; Pirchio, M.; Rafaelli, M. Machines for Non-Chemical Intra-Row Weed Control in Narrow and Wide-Row Crops: A Review. J. Agric. Eng. 2017, 48. Available online: https:/ / www.agroengineering.org/index.php/jae/article/view/583/629 (accessed on 23 July 2018). [CrossRef] 
99. Fendt Puts the New Robot 'Xaver' to Use. Available online: https:/ /www.fendt.com/int/fendt-xaver.html (accessed on 25 April 2018).

100. Developer, F. (Agritechnica, Hanover, Germany). Personal communication, November 2017.

(C) 2018 by the authors. Licensee MDPI, Basel, Switzerland. This article is an open access article distributed under the terms and conditions of the Creative Commons Attribution (CC BY) license (http://creativecommons.org/licenses/by/4.0/). 